\title{
Standard Contract Based on the Legal Positivist Paradigm of Study
}

\author{
Bachrul Amiq ${ }^{1}$, Wahyu Prawesthi ${ }^{2}$ \\ ${ }^{1.2}$ Universitas Dr. Soetomo \\ Surabaya, Indonesia \\ aba_amiq@unitomo.ac.id
}

\begin{abstract}
The conditions of this standard agreement can be provided by employing clauses that have been created or standardized and written in the form of groups with a large number that can be used for all agreements of the same type. The parties can create the standard agreement, although the contents are sometimes dictated by one of the parties. A unilateral standard agreement can also be defined as one that is determined by a party with a strong position in the agreement. It is actually the same as the legal requirements for an agreement agreement in general, which are contained in the provisions of Article 1320 of the Civil Code, as a legal requirement in the standard agreement or standard agreement. Even if it is included in the standard agreement, it is in violation of the parties' right to contract freely. However, as long as the parties do not object to the basic agreement being entered into, it can be regarded to be legitimate under Article 1320 of the Civil Code.
\end{abstract}

Keywords- Standard Agreement, Paradigm, Legal Positivism.

\section{INTRODUCTION}

In keeping with Indonesia's economic expansion and rapid pace, particularly in the domains of trading, buying and selling, and banking, both domestically and internationally. Of fact, the role of legal subjects in conducting business contacts with one another cannot be isolated from the trading and banking industry. As a result, not only are business relations marketing, but they also generate legal relationships between legal objects in trade and banking ties. The legal subjects are referring to a long-term connection with a binding contract. [1]

Even if it is governed by law, an agreement reached among legal subjects does not always result in a legal problem. Although the legal subjects' agreement does not generate legal problems in its implementation, it is possible that legal issues will arise and that a separate note will be included in the settlement. This is common in standard agreements, which have separate or predefined provisions.[2]

The Standard Agreement is frequently a polemic between the agreement that can be enforced based on each party's interests and is not contested. However, for one of the legal subjects, the normal agreement becomes a burden. The legal terms of the agreement have been set by the rules of Article 1320 of the Civil Code.[3] It is actually the same as the legal conditions for a standard agreement or standard agreement in general, which are mentioned in the provisions of Article 1320 of the Civil Code.[4]

An agreement, according to Bintang and Dahlan, has the same legal effect as legislation. That is, certain parties' agreements can be utilized as a legal basis for those who form them. To put it another way, the parties' agreement is legally binding. This is ensured by Article 1338 of the Civil Code, which provides that legally binding agreements are binding on individuals who form them. As a result, in the philosophy of law, a sort of philosophical settlement with a positivism paradigm approach is required. [5]

The legal positivism paradigm view can be utilized as a guide to create a legal notion that a standard agreement is truly not an issue provided legal subjects know the philosophical values contained in the agreement when carrying out the agreement. So that when the agreement is signed, the parties do not face any obstacles or compulsion, and the agreement does not become a source of contention. Even though standard agreements have become a habit in the connection between legal subjects while performing business, trade, or financial activities, they are still used. [6]

\section{RESEARCH METHOD}

A normative legal research method was applied in this work. Research resources in the form of primary and secondary legal materials are used in normative legal research (libraries). Mukti Fajar ND and Yulianto Achmad provide a framework for normative legal study in this case "Legal research in which the law is viewed as a set of rules. [7] Principles, norms, rules and regulations of laws and regulations, court decisions, agreements, and doctrines are all part of the normative system in question (teachings). Understanding is centered on the object of study in normative legal research, which is the law, which is viewed as a norm or rule of law. The three approaches are conceptual, statutory, and philosophical, and they are used to investigate ontological, epistemological, and axiological issues. [8]

\section{FINDINGS AND DISCUSSION}

Unquestionably tied to the standard clause itself, an understanding of the standard agreement cannot be directly provided prior to its standard.[9] However, this must be known on the basis of the whole agreement. 
Article 1313 of the Civil Code defines an agreement that results in engagements as "an act whereby one or more persons tie themselves to one or more persons bind themselves to one or more other persons." (Code of Civil Procedure) According to this definition, the parties have agreed to do something with assets that can be measured in money.[10] The form employs a written agreement in this situation, which refers to a written clause that is mutually agreed upon by reading or reading each of them. There is also a type of oral agreement in which the parties deliver the agreement straight to each other verbally and all parties hear the contents. [11]

The agreement reached is also enforceable, as long as it is not revoked (by the judge) at the request of the party who has the right to do so. As a result, such an agreement does not rely on a party's willingness to follow it. Vernietigbaar is the name given to such an arrangement. Pursuant to Subekti, four agreed requirements are required for an agreement to be valid, according to Article 1320 of the Civil Code, for people who bind themselves, are capable of reaching an agreement, on a specific issue and a lawful cause. [12]

The subject makes the agreement, the first two conditions are referred to as subjective conditions. If one of the subjective conditions is not met, the judge might revoke the agreement at the request of the individual involved. It is meant that the two subjects who enter into the agreement must agree, agree, or agree on the main aspects of the agreement being concluded, based on "agreement" or sometimes known as licensing. Meanwhile, an agreement becomes void if it is given owing to a misunderstanding or mistake, compulsion, or fraud, according to article 1321 of the Civil Code. [13]

The standpoint of justice, it is essential that the individual who enters into an agreement and is later "bound" by it has the ability to recognize and accept responsibility for his acts. Meanwhile, from the standpoint of law and order, because entering into an agreement entails risking one's wealth, that individual must have the legal right to act freely with one's wealth. [14]

This can be linked with Herlien Budiono's perspective that the person acting's expression of will includes the offer and acceptance prior to the agreement's closure. The encounter of wills, or the interlocking of each expression of will as given by the other party reciprocally and as perceived by each, is a critical step in the process of forging or completing an agreement. As a result, each party becomes legally obligated to the other. These criteria can be stated to be based on the foundation of such an agreement, even if it is a standardized agreement.[15]

The content of the standard agreement, also known as the standard form of the contract, comes as an indirect result of the Civil Code's inclusion of the principle of contract freedom (articles 1320 and 1338) The lack of substantial regulations capable of balancing the negotiation positions of the parties and the compulsion imposed on the other. Even legal professionals aren't on board with the conventional contract.[16] The standard contract is not an agreement, as Sluijer argued, because the role of business actors in the agreement is similar to that of a private legislator (legio particulere wetgever), and the conditions set by business actors in the agreement constitute law, not agreement. Pitlo claimed it was a coerced agreement (dwang contract). If there is a reason to be concerned about the presence of a standard agreement, it is because it contains an exoneration clause. An exoneration clause is a clause in a contract that allows one party to avoid paying full or partial compensation as a result of a broken promise or unlawful act. The existence of an exoneration clause, as can be shown, causes an imbalance in the bargaining stance between business actors (producers and consumers). [17]

The agreement is still in force today based on the opinion that allows or does not allow the existence of the standard agreement in business activities, trade, or the financial industry. As a result, the author will attempt to discuss the standard agreement of the ideals contained in positivism's teachings or paradigm. [18] The positivism paradigm was born as an antithesis to natural law theory, which some legal positivist circles believe has had setbacks and failures in practice. In the middle of lawsuits against social and moral views at the time, natural law was seen to be incapable of making demands. However, this paradigm retains natural law traits, such as the use of the normativity thesis to distinguish law from empirical facts. [19]

Legal positivism is a trend that arose as a result of the modernization of the legal system. Where positivism fits into the 18th-century Galilean tradition, which was further refined by Auguste Comte (1798-1857), who maintained that human life is a logical consequence of the law of cause and effect, with all of its circumstances and probability factors. Due to its nature, which tends to be oriented toward the notion of state sovereignty, which places the state in the sole position of being able to develop legal products that bring legal certainty and order to the rest of the community. As a result, most positivist thinkers are the forerunners of modern law (modern law) and modern government (modern government) (modern state).[20]

According to Comte, the positivistic law, which is the essence of the flow of rationalism, is a neutral law that does not take sides with any ideology. The law that was created must be based solely on a scientific process that is correct and scientific in nature, that is, it must have gone through scientific procedures; otherwise, it is considered unscientific and incorrect. The methodologies of the exact sciences cannot have a significant impact on the scientific law of positivism. Human history, according to Auguste Comte's reasoning, is the steady growth of the human way of thinking itself. This is the forerunner of the principle of legal certainty, which is the standard word in the legal form of positivism. By arguing that humans will be able to explain the reality of life not speculatively but concretely, certainly even absolute truth, with rational and positivistic empirical thinking, this is the forerunner of the principle of legal certainty, which is the standard word in the legal form of positivism.[21] 
The influence of Comte's positivism had a significant impact on John Austin's mindset, and he became a defender of the Positivism school by explicitly stating that valid law is only law that comes from coercive state institutions and must be obeyed by the community. The legal system of a country operates not because it is based on social life, the soul of the nation, or natural law, but rather because it is given positive form by the competent authority, namely the state itself. All of the ruler's orders are associated with the flow of legal positivism. This law is also often confused with law, in which the law is only perceived in its formal form and must be distinguished from its material form (legalism). The positivist school's popular phrase is "the law is the law." Furthermore, doctrinal-analytical philosophers argue that law is an order of norms that can only be produced by official state institutions, leading to the saying that there is no law other than state law.[23]

Orders, punishments, obligations, and sovereignty, according to Austin, are the four essential aspects of law. Provisions that lack these four components are just positive morals, not positive laws. The four elements are interconnected and can be explained in the following way: This element of the command means that one party wants the other party to do his will, and if the command is not carried out or obeyed, the other party will suffer. The order distinguishes between obligations to the governed and obligations to the sovereign, the latter of which can only be carried out if the sovereign is also the sovereign. Sovereignty can be exercised by a single person or a community of people (a sovereign person, or a sovereign body of persons).[24]

Austin's ideas were developed in the twentieth century by H.L.A. Hart, who believed that the characteristics of positivism in the science of law can be said that the law is an order from humans (command of human being). Furthermore, there is no absolute/significant link between the law that applies and the law that should apply. Included is the understanding that law is a logical, permanent, and closed system in which the right and correct legal decisions are usually obtained through logic from pre-determined legal regulations, regardless of social goals. Measures that are both political and moral. It cannot be made or maintained as a statement of reality that must be proven by rational argument, proof, or experiment in moral considerations. [25]

The related to the standard agreement that the author has stated at the beginning that every time there is an agreement there must be rules that regulate both those regulated by the authorities, in this case the state or the state, the expressions of the positivism paradigm developed by John Austin and Hart have similarities in assessing the law, if this is related to the standard agreement that the author has stated at the beginning that every time there is an agreement there must be rules that regulate both those regulated by the authorities, in this case the state or orders that are given by humans The order will be enforced in order to establish a legal order. And it will be really painful if you do not follow the established regulations. [26]

\section{CONCLUSION}

The party would obey the mutually agreed upon agreement in a standard agreement, it can truly become a legal order. In practice, the agreement is required, even if it contains a standard clause that states that the party who accepts the agreement bears the consequences stated in the clause. In Hart's opinion, humans can govern the will of other humans in law, as long as that will can be mastered through a logical, exact, and right legal system. So that other individuals who embrace this system can simply comprehend the commandment's meaning. As a result, it must have been assumed that every basic agreement established by the parties did not generate a compulsion. Although there are benefits and drawbacks to using this standard agreement in practice. However, if you look to positivism's analytical paradigm, you can see that while the law is coercive, it will not become a compulsion if it is obeyed and enforced.

\section{REFERENCES}

[1] R. Danendra, I. G. Ayu, K. Rachmi, and A. K. Jaelani, "Legal Protection of Non Wage Workers Rights After Omnibus Law,” Jurisprudentie, vol. 8, no. 13, pp. 85-99, 2021.

[2] L. C. Lintang, Adriano Martufi, and J.W. Ouwerker, "The Alternative Concepts of Blasphemy Law in Indonesia: Legal Comparison with Ireland and Canada," Bestuur, vol. 8, no. 2, pp. 121-128, 2020.

[3] M. Pungky and H. Wijaya, "Legislation Impediments in Reorganising Government Bodies in Indonesia," Bestuur, vol. 9, no. 1, pp. 1-16, 2021.

[4] S. R. Novikasari, D. Q. Ly, and K. Gershaneck, "Taxing Micro, Small and Medium Enterprises in Yogyakarta: Regulation and Compliance," Bestuur, vol. 9, no. 1, 2021.

[5] Saidah Fasihah Binti Che Yussoff and R. Nordin, "Freedom of Expression in Malaysia: Compatibility with the International Human Rights Standard Saidah,” Bestuur, vol. 9, no. 1, pp. 44-59, 2021.

[6] U. K. Mishra and A. Negi, "Transgender and the Right to Employment in India: Analysing the Trajectories of Discrimination," Bestuur, vol. 9, no. 1, pp. 34-43, 2021.

[7] H. J. Noor, K. Afkar, H. Glaser, and U. G. Mada, "Application of Sanctions Against State Administrative Officials Failing to Implement Administrative Court Decisions," Bestuur, vol. 9, no. 1, pp. 73-93, 2021.

[8] N. P. Hidayah, "The Implementation of Labor Development Principles According to Job Creation Law as a Reason to Protect Wages Rights," Bestuur, vol. 8, no. 2, pp. 121-128, 2020.

[9] W. B. Putri et al., "Medicolegal Perspective on Physician-Induced Demand Issue," Bestuur, vol. 9, no. 1, pp. 106-124, 2021.

[10] N. Ishak, R. R. Hasibuan, and T. S. Arbani, "Bureaucratic and Political Collaboration Towards a 
Good Governance System," Bestuur, vol. 8, no. 1, p. 19, 2020.

[11] N. Zubaidi, R. G. Pratama, and S. Al-Fatih, "Legal Perspective on Effectiveness of Pre-Work Cards for Indonesian People," Bestuur, vol. 8, no. 1, p. 9, 2020.

[12] L. Karjoko et al., "PATENT POLICY ON THE PHARMACEUTICAL SECTOR IN INDONESIA," vol. 23, no. 5, pp. 1-13, 2020.

[13] E. Sukmoro, A. Sulistiyono, and L. Karjoko, "The politic of law of PT. Kereta api Indonesia (persero) track access charge policy based on justice," Int. J. Adv. Sci. Technol., vol. 28, no. 20, pp. 353-361, 2019.

[14] Prasetio et al., "Problems of democratic and dignified election in indonesian simultaneously electoral era," Int. J. Criminol. Sociol., vol. 9, pp. 1701-1708, 2020.

[15] I. G. A. K. R. Handayani, L. Karjoko, and A. K. Jaelani, "Model Pelaksanaan Putusan Mahkamah Konstitusi yang Eksekutabilitas Dalam Pengujian Peraturan Perundang-Undangan di Indonesia," Bestuur, vol. 7, no. 1, pp. 36-46, 2019.

[16] S. D. Baranyanan, I. G. A. K. R. Handayani, and Isharyanto, "Political law of local government to resolve disputes adat law in Kei Island," Int. J. $A d v$. Sci. Technol., vol. 28, no. 20, pp. 494-499, 2019.

[17] E. T. Gomez, "Resisting the Fall: The Single Dominant Party, Policies and Elections in Malaysia," J. Contemp. Asia, vol. 46, no. 4, pp. 570590, 2016.

[18] F. Khairo et al., "Urgensi Contempt of Court Dalam Meningkatkan Wibawa," vol. 4, pp. 597-604, 2017.

[19] L. Karjoko, I. G. A. K. R. Handayani, A. S. Sudarwanto, D. W. Winarno, A. K. Jaelani, and W. N. Hanum, "THE CONSEQUENCE OF THE DECISION OF THE CONSTITUTIONAL COURT IN FORESTRY ON THE RECOGNITION OF TRADITIONAL FORESTS IN," J. Leg. Ethical Regul. Issues, vol. 24, no. 5, pp. 1-8, 2021.

[20] I. Iswantoro, "Strategy and Management of Dispute Resolution, Land Conflicts at the Land Office of Sleman Regency," J. Hum. Rights, Cult. Leg. Syst., vol. 1, no. 1, pp. 1-17, 2021.

[21] F. U. Najicha, "Oil and Natural Gas Management Policy in Realizing Equal Energy in Indonesia," $J$. Hum. Rights, Cult. Leg. Syst., vol. 1, no. 2, pp. 7179, 2021. 